\title{
Selecting Novel Material of Vegetable Pea for Mechanical Harvesting and Canning
}

\author{
Irina M. Kaigorodova - Ekaterina P. Pronina \\ All-Russian Research Institute of Vegetable Breeding and Seed Production, Laboratory of Breeding and Seed Production of Legume
} Cultures, 143080, Russia Poselok VNIISSOK, Moscow reg. Russia

\begin{abstract}
Summary: Breeding of novel pea cultivars is of significant interest in scope of increasing food shortages. The cultivars of new generation have to be highly technological and appropriate for mechanical treatment in all stages of planting. To provide higher outcome of plant products, pea is to be harvested for prolonged seasonal period, i.e. bred for conveyor usage. In this paper we presented the results of preliminary investigation of pea germplasm collection and studies on inheritance of flowering time in a series of crosses. We evaluated all hybrid progeny for duration of vegetation, lodging resistance and seed mass. Seven maturity groups were emphasized with most of obtained lines exhibiting an average duration of vegetation period measured as number of sterile nodes (11-15 for average fraction). As a result of this survey, the prospective genotypes for breeding new forms resistant to lodging and suitable for mechanical harvest were isolated. We propose a scheme of conveyor usage of new forms for sustainable delivery of stock for conversion industry. The obtained material is recommended for further improvement as the initial material for breeding.

Key words: canning industry, conveyor, harvesting, lodging resistance, maturity group, peas, vegetable crops
\end{abstract}

\section{Introduction}

Garden pea (Pisum sativum L.) is a valuable nutritive product for human consumption and animal feeding. It is characterized with numerous breeding types, such as grain, vegetable, forage, canning, non-food use, etc. As for vegetable varieties, they are widely planted in both private gardens and for field production. World production of vegetable (green) pea keeps growing steadily reaching 15.5 million tons in 2013, the main producer being China (FAO 2015).

One of the most actual requirements to the modern cultivars deals with their technological capacities, i.e. ability to produce high yield which satisfy the existing technologies. These define the main strategies in breeding of new cultivars of different maturity groups for conveyor delivery of green peas to processing industry.

To date, a significant faultline has opened between existing needs of plant breeding industry and degree of understanding of fundamental principles underlying some agriculturally valuable features. As for pea, little is known on inheritance of lodging resistance. This complex trait is obviously composed of numerous

Corresponding author:

kaigorodova-i@mail.r

Acknowledgements:

Authors express their gratitude to Dr. Andrey A. Sinjushin for his assistance during the preparation of the manuscript. factors, such as degree of stem lignifying, internode proportions, leaf morphology, etc. Some of genetic determinants of these features are already known (Sinjushin 2013), while others are poorly characterized. After identification of certain gene(s) or linked loci, a marker-assisted selection approach becomes applicable (e.g. Chen et al. 2015). However, for traits which are not dissected on molecular level a breeder can rely almost exclusively on crossing and individual selection of plants with preferred phenotypes.

In this connection, both extensive surveys on pea genetics and production of novel initial material for breeding are required. In this paper we described a breeding program aimed at obtaining the initial pea material for breeding cultivars suitable for mechanical harvest and industrial canning.

\section{Materials and Methods}

\section{Plant material and growing conditions}

In order to perform a comparative analysis, we used the germplasm from the collection of the Institute. In total, 370 samples of different cultivars and recombinant lines were studied, with 278 of foreign origin and 92 from the USSR or Russian Federation, including 45 bred in the Laboratory of Legume Cultures of the Institute.

As a result of the vegetable pea germplasm survey, we have chosen seven promising genotypes, namely 17PSI, Alfa, Radar, Izumrud, Afilla, Darunok and a 
lodging-resistant round-seed line 1003-10. These were considered the donors of economically valuable traits for breeding new vegetable pea cultivars adopted for mechanized harvest (Kaigorodova et al. 2013, Kaigorodova 2014). All parental forms and $F_{1}-F_{3}$ hybrids were grown on the experiment field of the AllRussian Research Institute of Breeding and Seed Production of Vegetables in the Western Moscow Region during the spring-sown seasons from 2010 to 2013. The experimental plots were prepared according to the standard methods applied in the Institute, with mechanical tillage and harrowing.

\section{Methods of survey}

During all growing seasons, we performed the phenotypic descriptions and the protocols regularly applied in the Institute (Belik \& Bondarenko 1979). The lodging-resistance was evaluated visually using a fourpoint grading scale in the phases of technical and biological maturity. The lodging-resistant forms were selected later and based on the coefficient of resistance, defined as a ratio between canopy height and stem length at the harvesting stage.

The hybridization of the selected vegetable pea genotypes was performed according to a diallel scheme using six parental forms. The simple and step crosses included the lodging-resistant line 1003-10. The mode of inheritance and the analysis of combination capacities were estimated according to Griffing (1956a, 1956b). The results of the hybridization analysis were evaluated according to Dospekhov (1985). The statistics of the obtained experimental data was carried out using dispersion and regression analysis (Dospekhov 1985) and with the MS Office Excel software.

\section{Results and Discussion}

The outcome of the hybridisation was new initial material of different maturity groups with different markers improving ability for mechanical harvest, such as afila leaf type, determinate growth type and increased lodging resistance. In $\mathrm{F}_{2}$ progenies, we isolated forms with the ultimate meanings of quantitative traits differing from parental lines. As a result, a wide range of lines was selected, ranging from very early to late maturing, with different stem length and first pod height.

Having processed the obtained quantitative results, we have selected the best parental forms which had produced the most promising progenies, such as 17PSI, Afilla, and Radar. If the line 17PSI was taken as the maternal parent, the hybrids were evaluated as promising, regardless of the paternal genotype. Potentially valuable genotypes were also found in the progenies of Afilla, as the maternal parent, and the cultivars Alfa, Izumrud, and Darunok. The crosses Izumrud $\times$ Radar and Darunok $\times$ Radar were also remarkable, since more than 20 potentially valuable lines were selected from their $\mathrm{F}_{3}$ hubrid generation. No recombinants with required characteristics were found in the progenies of Alfa $\times$ Radar, Radar $\times$ Izumrud and Radar $\times$ Afilla (Fig. 1).

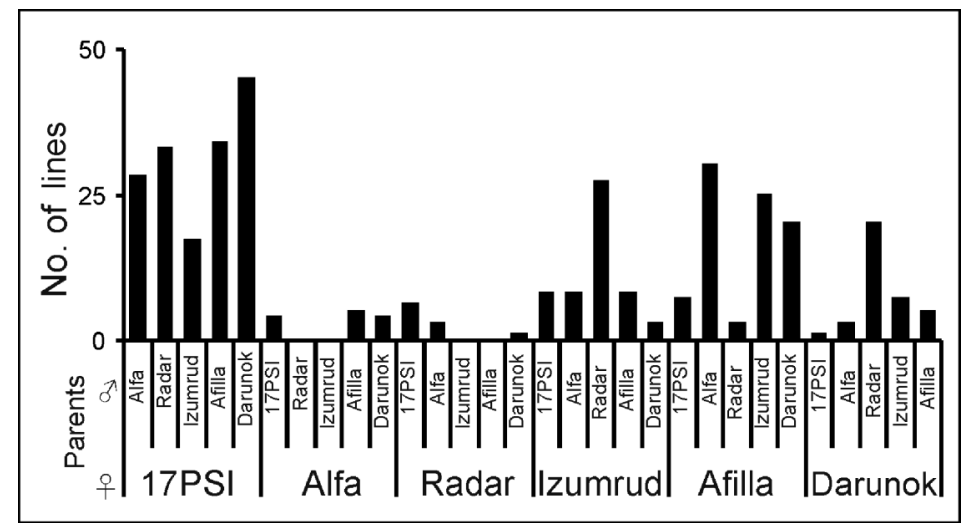

Figure 1. Number of vegetable pea lines suitable for mechanical harvesting selected from $\mathrm{F}_{3}$ progenies

Table 1. Characteristics of different maturity groups of the selected lines of vegetable pea

\begin{tabular}{lcc}
\hline Maturity group & Effective heat sum $\left({ }^{\circ} \mathrm{C}\right)$ & Period from germination to technical maturity (days) \\
\hline I & $<650$ & $<40$ \\
II & $650-690$ & $41-46$ \\
III & $690-720$ & $47-50$ \\
IV & $720-760$ & $51-56$ \\
V & $760-840$ & $57-64$ \\
VI & $840-900$ & $65-70$ \\
VII & $>900$ & $>70$ \\
\hline
\end{tabular}




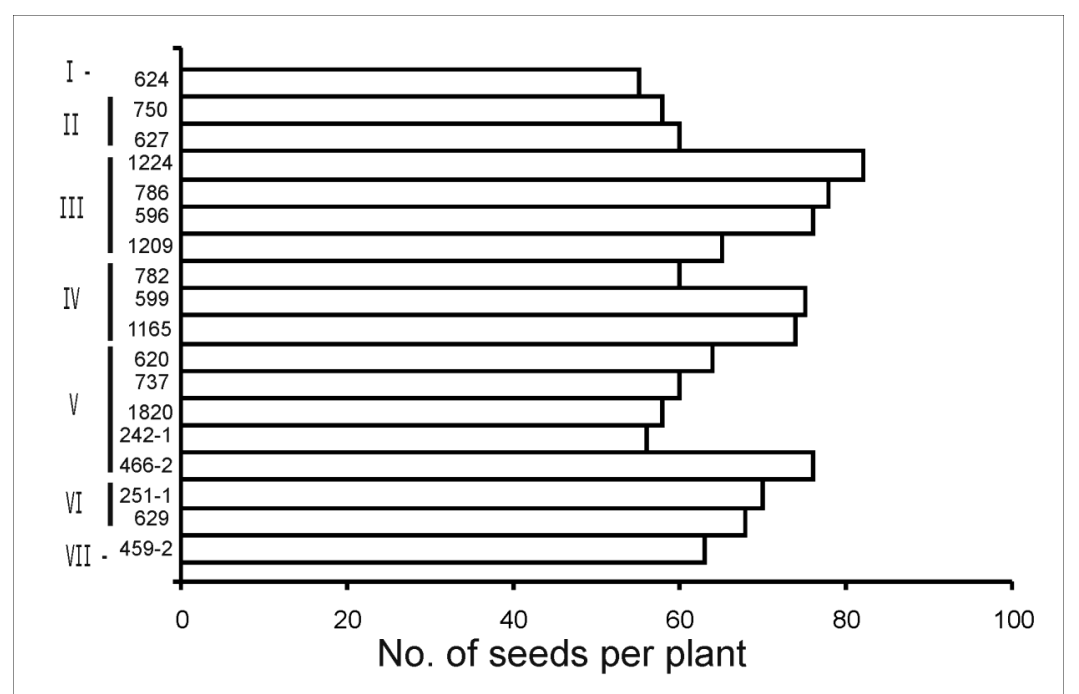

Figure 2. A conveyor of the selected perspective vegetable pea lines. Ordinates: selected lines (Arabic) in relation to the maturity groups (Roman).

In each maturity group, we selected stable lines with homogenous desirable traits, with increased productivity and resistance to lodging. These genotypes may form a conveyor of production of vegetable pea for industry with the duration of 45 to 50 days (Fig. 2). We also proposed a scheme of the use of novel lines for prolonged acquirement of vegetable stock. The lines of 2nd, 4th and 5th maturity groups appeared the most productive, having different durations of growing period from germination to technical maturity (Table 1).

Based on morphological studies and the analysis of starch grains structure, we selected 18 stable lines available for canning. They are all characterized with green marrow seeds ( $i r$ genotype). The most prospective list for breeding is 17PSI, Radar and Afilla, since their progenies produced the majority of the lines with desirable agronomic traits. Out of 18 selected lines, 11 were obtained from the crosses with 17PSI as the maternal component, 9 from the crosses with Radar as the paternal line, and 5 from the crosses with Afilla as both maternal and paternal form.

To increase the lodging tolerance, all the selected recombinants were additionally included into simple or back-crosses with the lodging-resistant line 1003-10, with a resistance coefficient of higher than 0.95 . The lines prospective for mechanical harvest were selected in hybrid progenies of $\mathrm{F}_{2}-\mathrm{F}_{3}$ generations. The higher outcome of such forms was obtained if the line 1003-10 acted as the maternal parent (Fig. 3). The highest number of potentially valuable genotypes was selected in the hybrid population of $\mathrm{F}_{2}$ generation of the cross $\{1003-10 \times[(17 \mathrm{PSI} \times$ Alfa $) \times 17 \mathrm{PSI}]\}$.

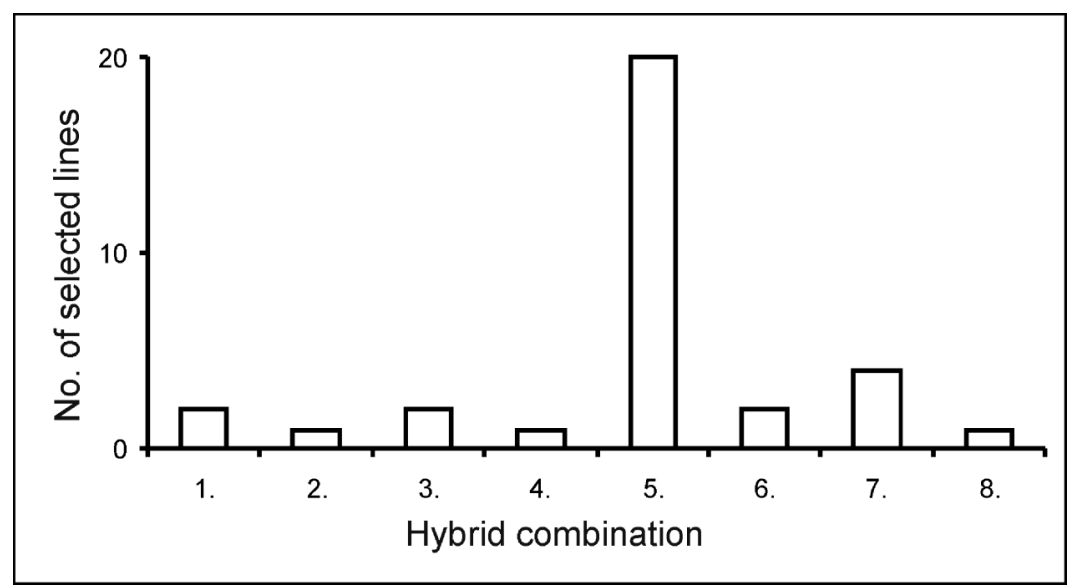

Figure 3. Number of perspective lines selected from the hybrid progenies of different crosses with the line 1003-10. Combinations: 1 - 1003-10 $\times$ Izumrud; 2 - Izumrud $\times$ 1003-10; 3 - 1003-10 $\times$ [(Darunok $\times 17 P S I) \times$ Darunok $] ; 4-[($ Darunok $\times$ $17 \mathrm{PSI}) \times$ Darunok $] \times 1003-10 ; 5-1003-10 \times[(17 \mathrm{PSI} \times$ Alfa $) \times 17 \mathrm{PSI}] ; 6-[(17 \mathrm{PSI} \times$ Alfa $) \times 17 \mathrm{PSI}] \times 1003-10 ; 7-[(17 \mathrm{PSI} \times$ Radar $) \times 17$ PSI $\times 1003-10 ; 8-1003-10 \times($ Radar $\times$ Izumrud $)$. 


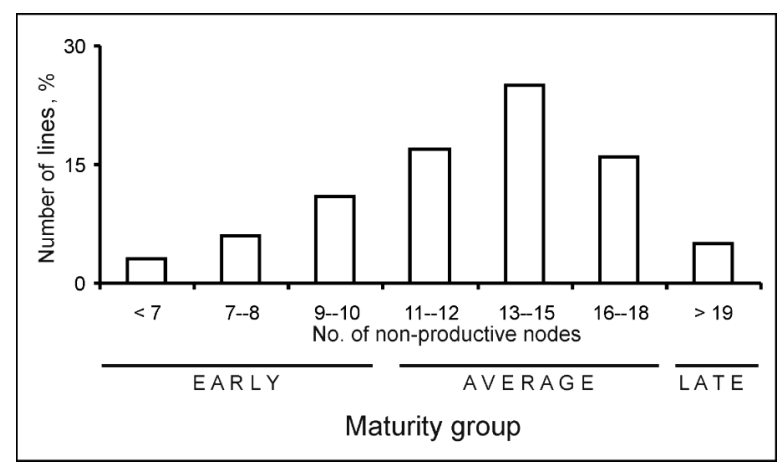

Figure 4. Distribution of the selected lines of vegetable pea according to maturity groups

In total, 83 lines with desirable traits were selected, thus representing the initial material for breeding vegetable pea for mechanical harvest (Fig. 4). Most of the selected lines belonged to the earlyand mid-maturing groups. We also obtained very early and very late maturing lines from the mutual crosses of all parental components.

\section{Conclusions}

As the result of this study, we selected 83 lines with the most favorable combination of features appropriate for further breeding of new cultivars. Most of chosen lines belong to early and average maturity groups, but they all exhibit increased lodging resistance. Further work with this initial material is expected to result in production of conveyor series of cultivars which may be used for canning industry.

\section{References}

Belik, V. F., \& Bondarenko, G. L. (eds.) (1979). Methods of field experiments in vegetable and melon growing (In Russian). NIIOKH, Moscow.

Cheng, P., Holdsworth, W., Ma, Y., Coyne, C. J., Mazourek, M., Grusak, M. A., Fuchs, S., \& McGee, R. J. (2015). Association mapping of agronomic and quality traits in USDA pea single-plant collection. Mol. Breed., 35: 75. (doi:10.1007/s11032-015-0277-6)

Dospekhov, B. A. (1985) Methods of field experiments (In Russian). Agropromizdat, Moscow.

FAO (2015). FAOSTAT. Retrieved from http://faostat3.fao.org/, accessed 11 November 2015

Kaygorodova, I. M., Pronina, E. P., \& Pyshnaya, O. N. (2013). The study of promising samples of peas as vegetable genetic resources in breeding for quality and productivity (In Russian). Ovoshchi Rossii, 1: 30-34.

Griffing, B. (1956a). A generalized treatment of the use of diallel crosses in quantitative inheritance. Hered., 10: 31-50.

Griffing, B. (1956b). Concept of general and specific combining ability in relation to diallel crossing systems. Austr. Journ. Biol. Sci., 9: 463493.

Kaigorodova, I. M. (2014). Design of initial material of vegetable pea (Pisum sativum L.) of different maturity groups for mechanical harvesting (In Russian). Doctoral dissertation. Lomonosov Moscow State University.

Mamayeva, E. V. (1985). Methodical guidance for breeding and seed production of vegetable legume crops (In Russian). VASKhNIL, Moscow.

Sinjushin, A. (2013). Mutation genetics of pea (Pisum sativum L.): What is done and what is left to do. Ratar. Povrt., 50(2): 36-43. (doi:10.5937/ratpov50-4191)

\section{Selekcija novog materijala graška za mehanizovanu žetvu i konzerviranje}

\section{Irina M. Kaigorodova - Ekaterina P. Pronina}

Sažetak: Stvaranje novih sorti graška je od velikog značaja s obzirom na povećanu potražnju za hranom. Sorte nove generacije moraju biti na visokom tehnološkom nivou i podobne za mehanizovane tretmane u svim fazama. U cilju dobijanja visokih prinosa, grašak bi trebalo da se oplemenjuje za korišćenje na konvejeru, tj. za produženi period vegetacije. U ovom radu su dati rezultati prethodnog istraživanja nasleđivanja vremena cvetanja na kolekciji germplazme graška. Hibridno potomstvo je ocenjeno u odnosu na dužinu vegetacije, otpornost na poleganje i masu semena. Odabrani su poželjni genotipovi za oplemenjivanje novih formi otpornih na poleganje i pogodni za mehanizovanu žetvu. Predložena je shema korišćenja na konvejeru za održivu isporuku industriji konzerviranja. Dobijeni materijal se preporučuje za dalja poboljšanja kao početni oplemenjivački materijal.

Ključne reči: konzervacija, otpornost na poleganje, grupa zrenja, žetva, povrće, grašak, konvejer 